\title{
Ichnology and sedimentary environment of Cretaceous redbeds in the Ruyang Basin, western Henan Province, China
}

\author{
Hu BIN ${ }^{1,2 *}$, Wang CHANGZHENG ${ }^{1}$, Wang YUANYAUN ${ }^{1}$ \& Song HUIBO ${ }^{1,2}$ \\ ${ }^{1}$ Institute of Resources and Environment, Henan Polytechnic University, Jiaozuo, 454000, Henan, China; hubin1952@163.com \\ ${ }^{2}$ Key Laboratory of Biogenic Traces and Sedimentary Minerals of Henan Province, Jiaozuo, 454000, Henan, China \\ * Corresponding author
}

Bin H., Changzheng W., Yuanyaun W. \& Huibo S. 2014. Ichnology and sedimentary environment of Cretaceous redbeds in the Ruyang Basin, western Henan Province, China. [Icnología y ambiente sedimentario de las capas rojas del Cretácico de la cuenca de Ruyang, Oeste de la provincia de Henan, China]. Spanish Journal of Palaeontology, 29 (2), 151-164.

\begin{abstract}
A sequence of terrestrial clastic redbeds of Cretaceous age is exposed in the Ruyang Basin of western Henan Province in China. The rocks consist of conglomerate, sandstone, siltstone and mudstone containing the ichnofossils Psilonichnus, Arenicolites, Palaeophycus, Scoyenia, Planolites, Skolithos and other burrows and rhizoliths. The beds also contain the dinosaur fossils Huanghetitan ruyangensis and Zhongyuansaurus luoyangensis. On the basis of the lithology, sedimentary structures and ichnofossils, it is suggested that the sedimentary environments of the Ruyang Basin during the Cretaceous were primarily alluvial fan in character, including middle fan and fan edge subfacies. In this sedimentary setting, eight lithofacies types are distinguished, and two ichnoassemblages are recognized: (1) ScoyeniaSkolithos ichnoassemblage occurring in braided fluvial deposits of an alluvial fan system, and (2) PsilonichnusPalaeophycus ichnoassemblage occurring in shallow pond or lake deposits at the fan edge.
\end{abstract}

Keywords: Ruyang Basin, alluvial fan, Cretaceous, trace fossils, China.

\section{RESUMEN}

En la cuenca de Ruyang, al oeste de la provincia china de Henan, aflora una secuencia de capas rojas clásticas terrestres de edad cretácica. Se trata de conglomerados, areniscas, limolitas y lutitas que contienen los icnofósiles Psilonichnus, Arenicolites, Palaeophycus, Scoyenia, Planolites, Skolithos, otras trazas y rizolitos. Las capas también engloban fósiles de los dinosaurios Huanghetitan ryuangensis y Zhongyuansaurus luoyangensis. En base a la litología, las estructuras sedimentarias y los icnofósiles, se sugiere que los ambientes sedimentarios de la cuenca de Ruyang durante el Cretácico fueron primordialmente de tipo abanico aluvial, incluyendo subfacies de abanico medio y de borde de abanico. En este contexto sedimentario, se distinguen ocho tipos de litofacies y se reconocen dos icnoasociaciones: (1) Icnoasociación de Scoyenia-Skolitos en depósitos fluviales anastomosados de un sistema de abanico aluvial, e (2) icnoasociación de Psilonichnus-Palaeophycus en charcas someras o depósitos lacustres en el borde del abanico.

Palabras clave: Cuenca de Ruyang, abanico aluvial, Cretácico, icnofósiles, China. 


\section{INTRODUCTION}

The Ruyang Basin is located in Ruyang County of Henan Province, China (Fig. 1), and it is situated in the area between the southern margin of the North China Plate and the Qinling Orogenic Belt. It is a rifted basin controlled by northwest and northeast-trending faults. In the Early Cretaceous, the rift basin formed with a northwest strike, inclined to the east and south. This basin is rhomb-shaped (Huang et al., 2005; Lv et al., 2005; Yu et al., 2007; Zhang et al., 2007). Body fossils of the dinosaurs Huanghetitan ruyangensis and Zhongyuansaurus luoyangensis have been found in this basin (Xu et al., 2010). However, the trace fossils have not been studied in detail. The aim of this paper is to describe the ichnologic and sedimentary features and to interpret the palaeoenvironment of the Cretaceous dinosaur-bearing strata.

\section{GEOLOGIC SETTING}

Based on lithology and fossils, the Cretaceous strata of this basin are divided into the Lower Cretaceous Jiudian, Xiahedong and Haoling Formations and the Upper Cretaceous Shangdonggou Formation (Fig. 2). The lower part of the Jiudian Formation is conglomerate, and the middle-upper part is crystalline tuff. The thickness of the formation ranges from 354 to $1,806 \mathrm{~m}$, and it unconformably overlies the Mesoproterozoic Ruyang Group or Xionger Group. The lower part of the Xiahedong Formation is composed of conglomerate mixed with sandy conglomerate, lithic sandstone, and muddy siltstone with conglomerate. The upper part is composed of conglomerate interbedded with muddy siltstone. The thickness ranges from 79 to $363 \mathrm{~m}$, and it conformably overlies the Jiudian Formation, which underlies the

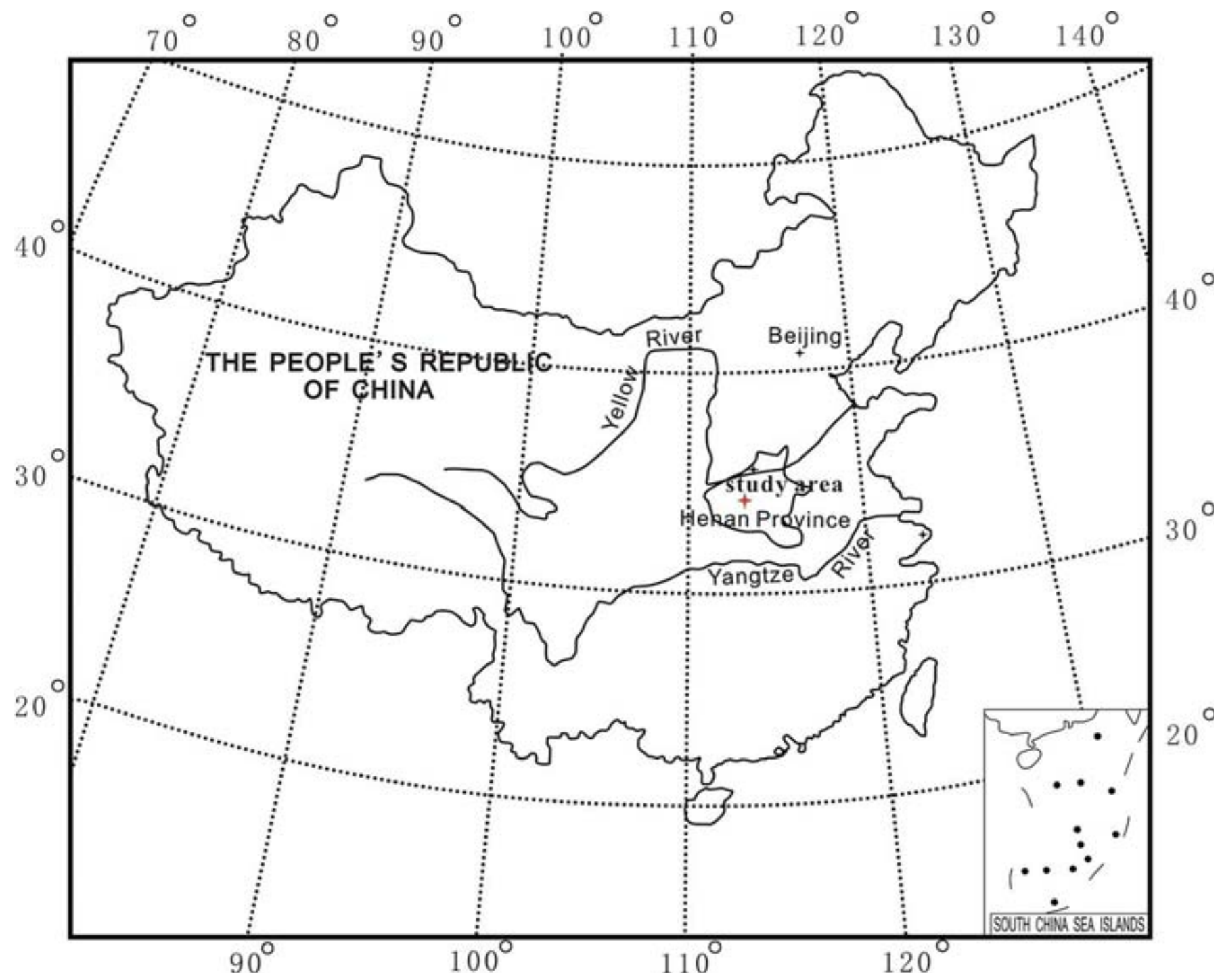

Figure 1. Location of the study area in Henan Province, China. 
Haoling Formation. The Haoling Formation is composed of conglomerate interbedded with muddy siltstone and silty mudstone, mixed with sandy conglomerate containing calcareous concretions. The body fossils include dinosaurs, bivalves and ostracodes. The age is Early Cretaceous. The thickness ranges from 418 to $625 \mathrm{~m}$, and it conformably overlies the Xiahedong Formation and underlies the Shangdonggou Formation. The Shangdonggou Formation is composed of brownish red siltstone, off-white sandy conglomerate, mixed with conglomerate, and it contains body fossils of the dinosaurs Huanghetitan ruyangensis and Zhongyuansaurus luoyangensis. The thickness ranges

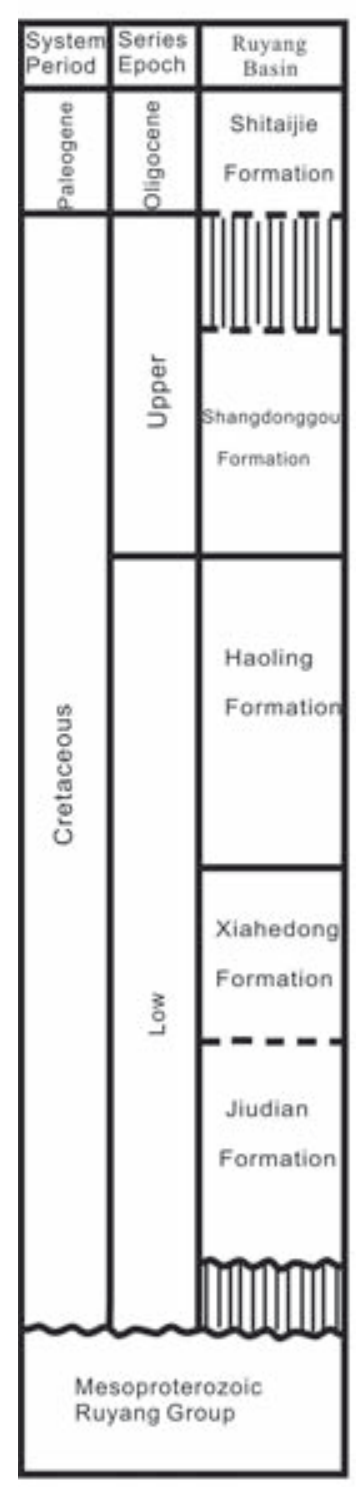

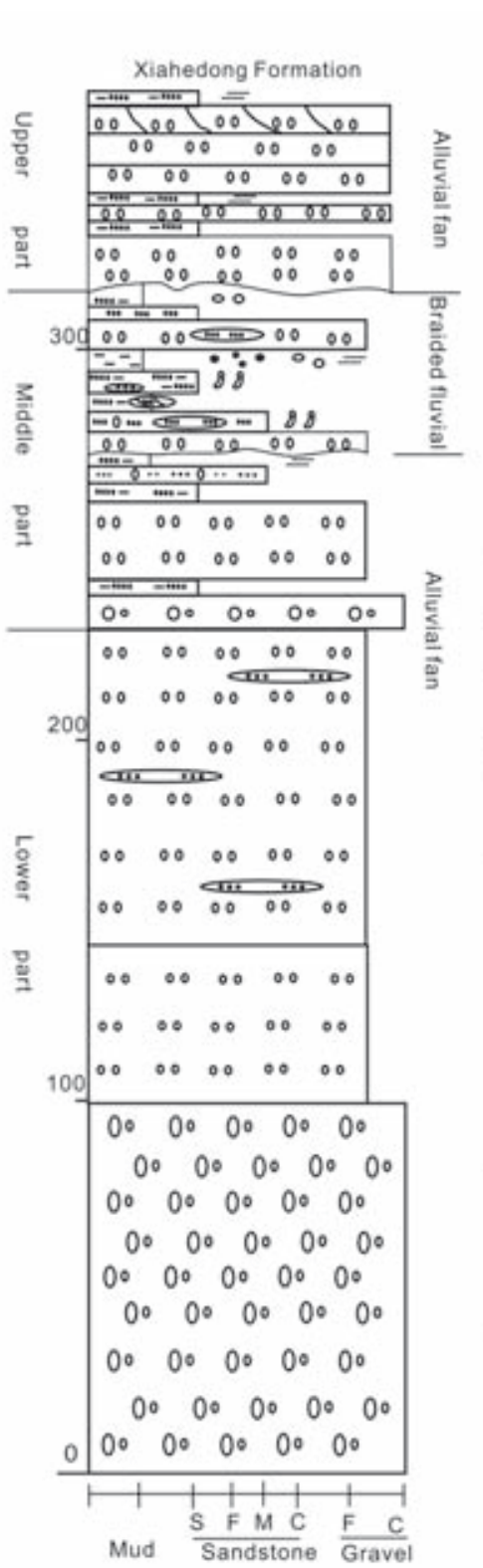
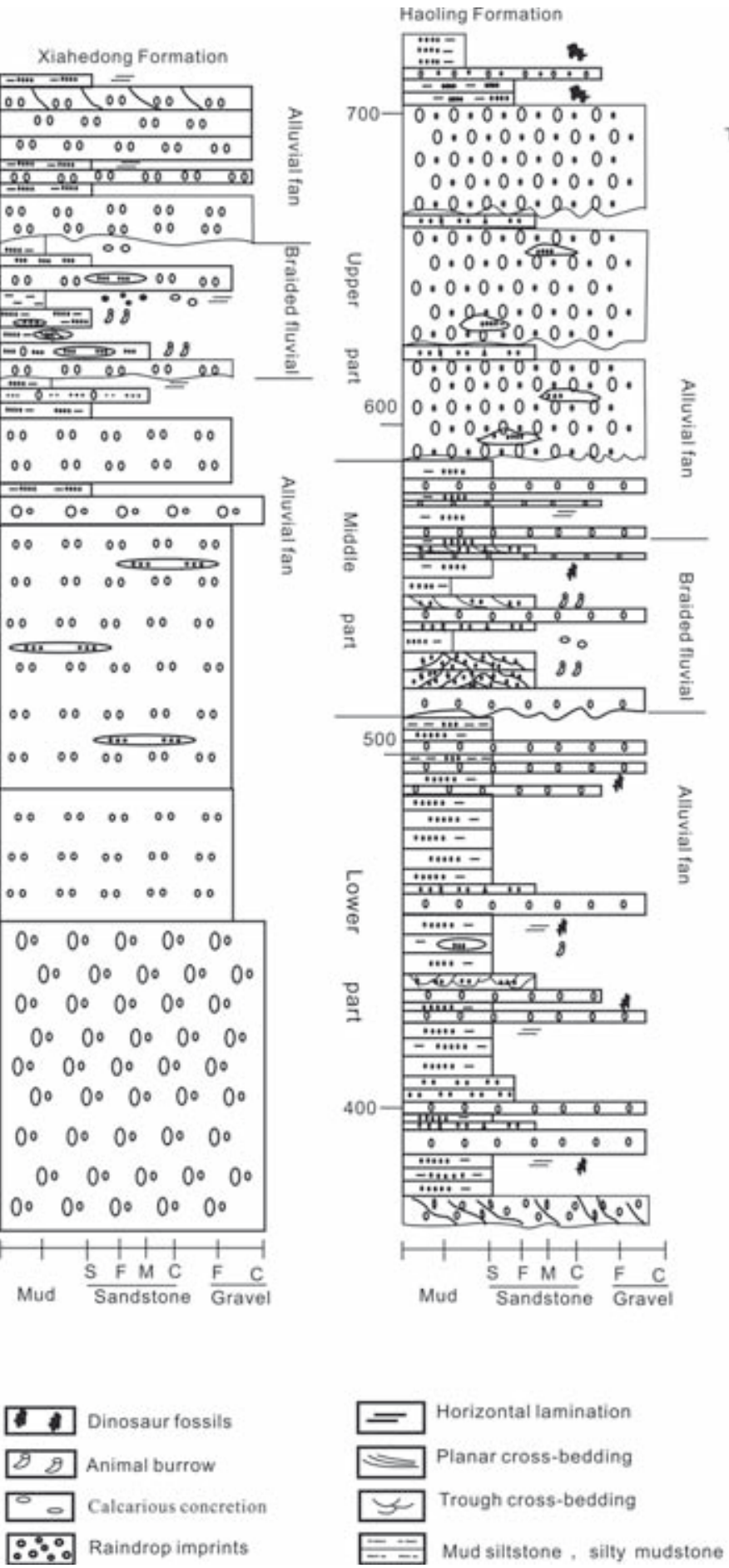

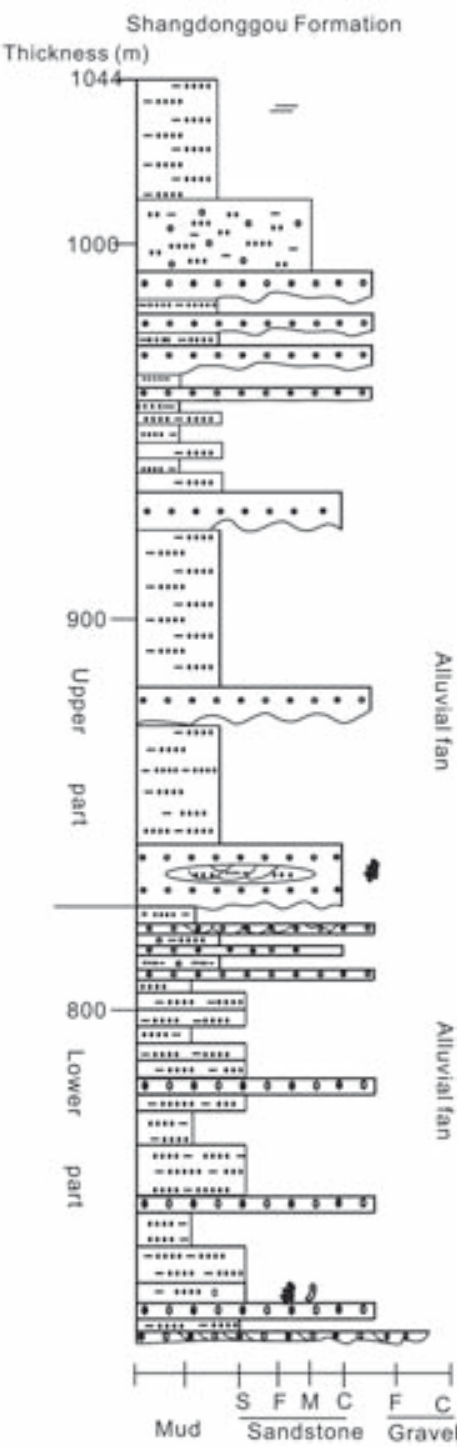

$\Rightarrow$ Siltstone

Medium-fine sandstone

Figure 2. Stratigraphic columns of the Cretaceous strata in the Ruyang Basin. 
from 331 to $341 \mathrm{~m}$. The age is Late Cretaceous. Facies types, lithologic composition, depositional sequence and sedimentary structures of the Cretaceous redbeds in the Ruyang Basin are analyzed in detail (Fig. 2).

\section{LITHOFACIES DESCRIPTION}

Eight lithofacies are distinguished on the basis of lithology, sediment texture, primary sedimentary structures and fossil content. A summary of the description and interpretation of the sedimentary facies is offered in Table 1. the largest clasts may be up to dozens of centimeters. The texture and fabric of the conglomerate beds are unsorted and disorganized, and the clasts do not show any significant stratification. The conglomerate clasts are subangular to rounded. The matrix is composed of sand and mud, as in lithofacies Gcm (Fig. 3b). The conglomerate beds are capped by either fine- to medium-grained sandstone or by purplish red laminated silty mudstone beds. The capping beds usually contain small pebbles that are composed of the same material as the conglomerate clasts.

The massive and disorganized nature of the beds indicates episodes of rapid debris flow sedimentation, where sediment concentration was high. The basal erosional scour, lack of graded bedding, lack of stratification, and poor grain sorting indicates debris flow deposition.

Table 1. Description and interpretation of the lithofacies.

\begin{tabular}{|c|c|c|c|c|}
\hline Lithofacies & Lithology and texture & Sedimentary structures & Bioturbation & Interpretation \\
\hline $\mathrm{Gmm}$ & $\begin{array}{l}\text { Matrix-supported, } \\
\text { massive conglomerate }\end{array}$ & $\begin{array}{l}\text { No grading or weak } \\
\text { graded, scour structures }\end{array}$ & None & $\begin{array}{l}\text { Subaerial rapidly } \\
\text { plastic debris flow high- } \\
\text { strength, viscous }\end{array}$ \\
\hline $\mathrm{Gcm}$ & $\begin{array}{l}\text { Clast-supported massive } \\
\text { conglomerate, sandy } \\
\text { conglomerate }\end{array}$ & Weak grading to ungraded & None & $\begin{array}{l}\text { Subaerial pseudoclastic } \\
\text { debris flow }\end{array}$ \\
\hline $\mathrm{Gm}$ & Massive conglomerate & Weak imbricate structure & None & Channel lag deposits \\
\hline Gt & $\begin{array}{l}\text { Clast-supported } \\
\text { conglomerate }\end{array}$ & $\begin{array}{l}\text { Tabular cross-bedding, } \\
\text { trough cross-bedding, } \\
\text { scour structures }\end{array}$ & None & $\begin{array}{l}\text { Small channel lag } \\
\text { deposits }\end{array}$ \\
\hline St & $\begin{array}{l}\text { Medium-fine grained } \\
\text { lithic sandstone, mixed } \\
\text { with pebbly sandstone }\end{array}$ & $\begin{array}{l}\text { Trough and wedge cross- } \\
\text { bedding }\end{array}$ & $\begin{array}{l}\text { Palaeophycus, Skolithos, } \\
\text { dinosaur fossils }\end{array}$ & Channel fills \\
\hline $\mathrm{Sm}$ & $\begin{array}{l}\text { Medium-fine grained } \\
\text { sandstone }\end{array}$ & Massive & None & Gravity current \\
\hline Fm & $\begin{array}{l}\text { Silty mudstone, } \\
\text { intercalated grayish fine } \\
\text { grained sandstones }\end{array}$ & Massive & $\begin{array}{l}\text { Dinosaur fossils, } \\
\text { Psilonichnus, } \\
\text { Arenicolites, other } \\
\text { burrows }\end{array}$ & $\begin{array}{l}\text { Shallow pond or lake } \\
\text { within fan edge }\end{array}$ \\
\hline Fsm & $\begin{array}{l}\text { Brownish red muddy } \\
\text { siltstone and silty } \\
\text { mudstone }\end{array}$ & $\begin{array}{l}\text { Horizontal lamination, } \\
\text { massive, raindrop } \\
\text { imprints }\end{array}$ & $\begin{array}{l}\text { Dinosaur fossils, } \\
\text { Scoyenia, Planolites, } \\
\text { Palaeophycus, Skolithos, } \\
\text { rhizoliths, other burrows }\end{array}$ & $\begin{array}{l}\text { Sheet flood deposition or } \\
\text { flood plain }\end{array}$ \\
\hline
\end{tabular}

\subsection{Lithofacies Gmm/Gcm}

This lithofacies consists of matrix-supported massive conglomerate $(\mathrm{Gmm})$ and clast-supported massive conglomerate $(\mathrm{Gcm})$. It occurs in the Cretaceous sections throughout the whole study area. These massive conglomerate beds are dozens of centimeters to several meters thick. The size of the clasts is mostly 3 to $20 \mathrm{~cm}$, but
The matrix-supported massive conglomerate lithofacies (Gmm) (Fig. 3a) is interpreted to represent a rapidly deposited subaerial debris flow (Nemec et al., 1980). Their interbedded occurrence with alluvial channel-fill sandstones indicates reworking and winnowing of earlier deposited debris flows (lithofacies $\mathrm{Gcm}$ ) by alluvial currents. The lithofacies $\mathrm{Gcm}$ is interpreted to represent a subaerial debris flow. 

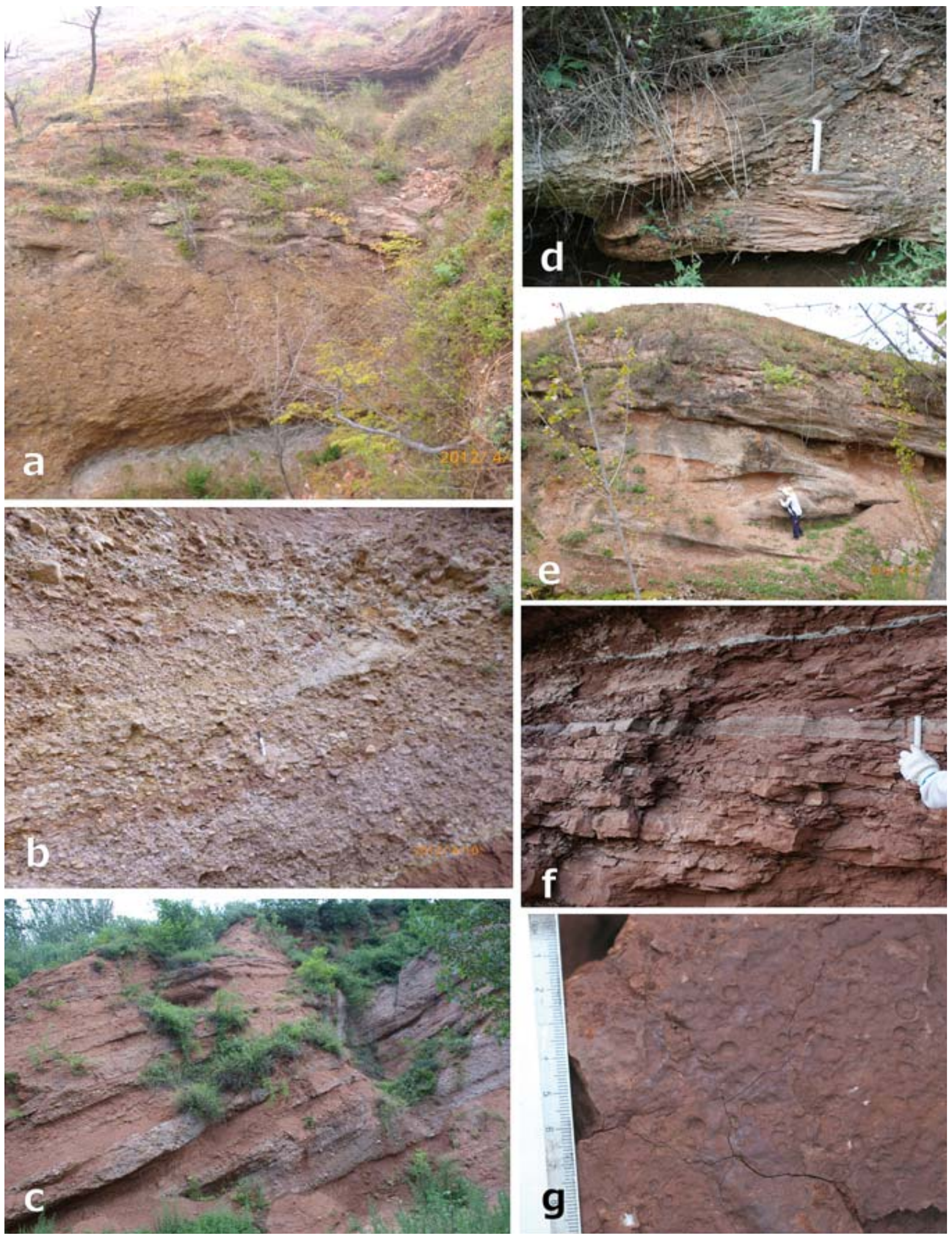

Figure 3. Outcrop characteristics of sedimentary structures in the Cretaceous strata of the Ruyang basin. a) Outcrop of the Haoling Formation, showing matrix-supported massive conglomerate at the bottom. b) Clast-supported massive conglomerate. c) Massive conglomerate. d) Trough cross-bedding sandstone and trough crossbedding conglomerate. e) Wedge crossbedding in sandstone. f) Brownish red siltstone and silty mudstone. g) Raindrop imprints. 


\subsection{Lithofacies $\mathbf{G m} / \mathbf{G t}$}

This facies association consists of massive conglomerate $(\mathrm{Gm})$ and trough crossbedded conglomerate (Gt), and it occurs in the Xiahedong and Haoling Formations. The Facies Gm consists of purplish red, gray and purple conglomerate, and it is overlain by fine to mediumgrained, crossbedded sandstone. The conglomerate clasts are subangular to subrounded, and they exhibit an imbricated arrangement. Conglomerate beds exhibit inverse grading and concave-down lenticular structures (scour and fill structures), which suggests reworking in an alluvial channel. Large channel lag deposits form large tabular crossbedding, as in Gm (Fig. 3c). Facies Gt with trough cross-bedding apparently formed in small channel lag deposits (Fig. 3d).

\subsection{Lithofacies St}

This lithofacies consists of gray to grayish green lithic sandstone with large-scale, trough and wedge crossbedding, containing fine gravel, abundant trace fossils and well developed erosive structures (Figs 3d-3e). Bed thickness of the sandstone ranges from 1 to $7.6 \mathrm{~m}$, sometimes changing laterally to siltstone or mudstone, and the sandstone beds in this lithofacies are thinner than the conglomerate and siltstone beds. These sedimentary characteristics indicate that the lithofacies St formed in the channel fills. This lithofacies can be found in the Lower Cretaceous Xiahedong and Haoling Formations and the Upper Cretaceous Shangdongou Formation.

\subsection{Lithofacies Sm}

This lithofacies is composed of massive, gray to grayish green, fine to coarse-grained pebbly sandstone. It is commonly found in the Lower Cretaceous Haoling Formation and the Upper Cretaceous Shangdongou Formation. This lithofacies is not well exposed, and its lateral continuity is uncertain. The massive sandstone beds are overlain by silty mudstone or conglomerate beds, sometimes in an upward fining sequence, i.e., conglomerate to massive sandstone to mudstone beds, or occurring as an interlayer within the conglomerate beds. This lithofacies formed in a mid-fan or fan-edge position within the alluvial fan system.

\subsection{Lithofacies Fm/Fsm}

Lithofacies Fm is characterized by massive silty mudstone intercalated with gray fine-grained sandstone, and lithofacies Fsm is dominated by muddy siltstone and silty mudstone. The mudstone and siltstone can be traced laterally for dozens of meters, and the individual layer thickness of Fm and Fsm ranges from 1.0 to $12.0 \mathrm{~m}$, but they may change locally to sandstone and conglomerate.

Lithofacies Fm appears only in the Haoling Formation, where it is characterized by silty mudstone and intercalated gray fine-grained sandstone. In outcrop section, the lithofacies Fm changes laterally to fine-grained sandstone and silty mudstone, in which the trace fossils are mostly "U", "W", "J" and "Y"-shaped burrows. Calcareous concretions occur in isolation within the mudstones. This lithofacies is interpreted as a deposit in a seasonally or climatically controlled intra-fan pond within a foodplain.

Commonly, brownish red siltstone and silty mudstone alternate in the lithofacies Fsm (Fig. 3f). Sometimes siltstone also is mixed with sandy conglomerate and conglomerate. The silty mudstone beds are disturbed by root traces. On weathered outcrops, calcareous concretions commonly are encased in mudstone, and their distribution is either isolated or stratified.

Some raindrop imprints occur irregularly on the surfaces of mudstone beds (Fig. 3g). The trace fossils Scoyenia, Planolites, Palaeophycus, Skolithos and other burrows, as well as vertebrate fossils, also are common. This lithofacies Fsm is interpreted as representing foodplain deposits between fluvial fan channels and braided river channels.

\section{DEPOSITIONAL ENVIRONMENTS}

Based on lithology, physical sedimentary structures, sedimentary sequences, bed boundaries and fossil contents, two kinds of depositional environment were recognized in the succession studied (Figs 2, 4): (1) alluvial fan environment and (2) braided fluvial environment.

\subsection{Alluvial fan environment}

Alluvial fan deposits are well developed in the Cretaceous sequences in this basin. The base of the Xiahedong Formation is a matrix-supported tuff conglomerate. The lower part is a conglomerate mixed with brownish red muddy siltstone containing gravel and off-white lithic sandstone. The pebble grains range from round to subangular. The composition of the pebbles is mainly volcanic rock derived from the middle Proterozoic Xionger Group. The grain size decreases upward in the sedimentary sequence. Lateral continuity of bedding is poor. Generally, outcrop profiles display a sequence of graded beds that become thinner and finer upwards in the alluvial fan (Fig. 4B). The upper part of the Xiahedong Formation is brownish red, grayish-green sandy conglomerate interbedded with purplish red silty mudstone containing 

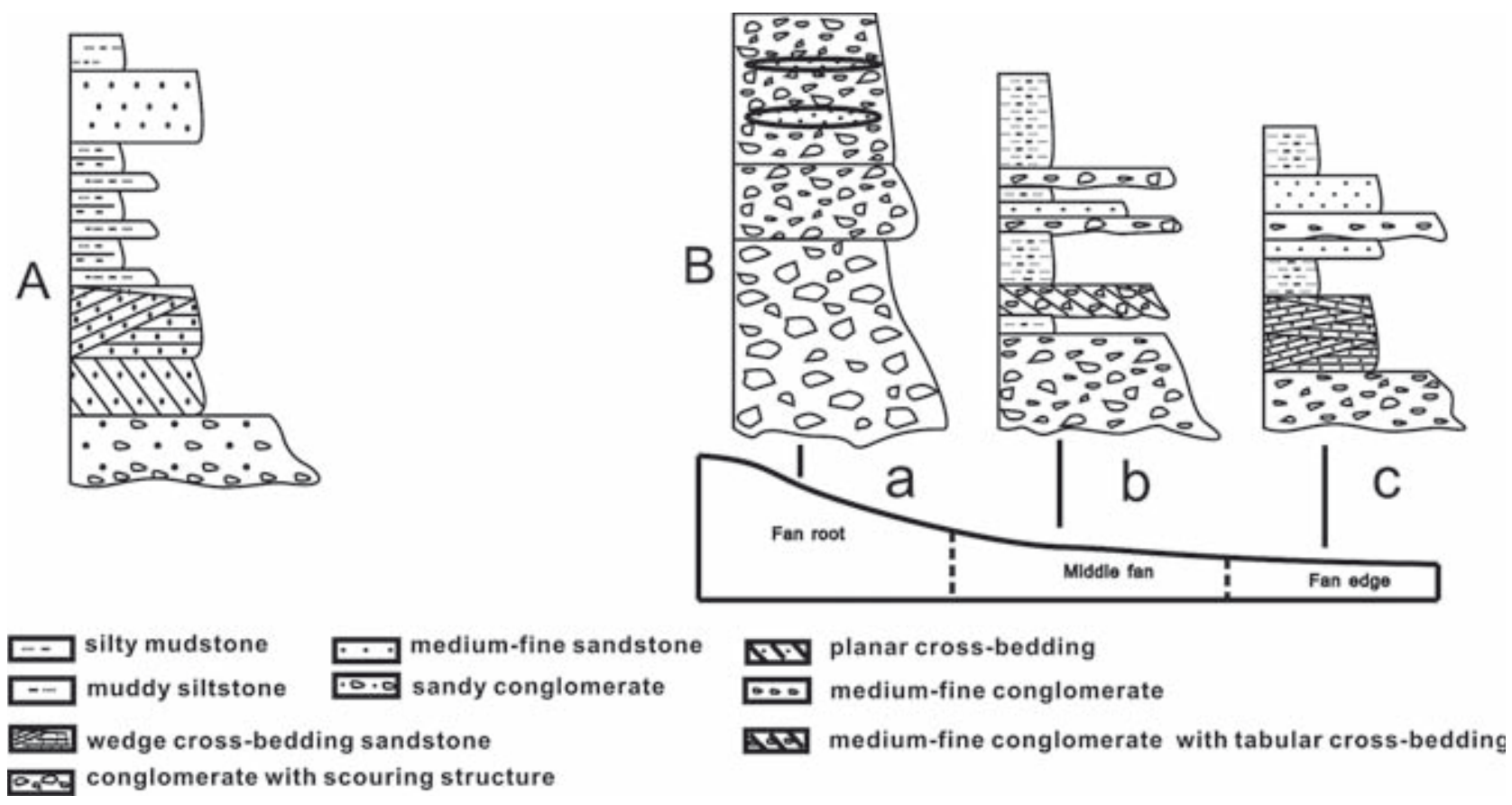

Figure 4. Sedimentary sequences of an alluvial fan system in the Ruyang Basin.

calcareous concretions. The sedimentary features include horizontal bedding, tabular crossbedding and erosional scour structures. The sedimentary system is mainly debris flow and channel fill deposits in a mid-fan (Fig. 4B-b) and edge-fan position (Fig. 4B-c) within the alluvial fan system (Fig. 4B).

The sedimentary characteristics of the Haoling and Shangdonggou Formations are similar to those in the Xiahedong Formation, except for no development of plant roots in the depositional environment. The principal difference is that the lower member of Haoling Formation displays lithofacies Fm, which formed in a fan edge environment.

\subsection{Braided fluvial environment}

The braided fluvial system developed is represented by lithofacies St and Fsm. Lithofacies St is characterized by medium to fine-grained lithic sandstones with trough and wedge crossbedding (Table 1), mixed with pebblebearing sandstone. The lower part of this sedimentary sequence contains the conglomerate bed, and the upper part contains alternating layers of brownish red siltstone and silty mudstone (Fig. 4A), in which the silty mudstone beds are commonly thicker than the siltstone beds. Many trace fossils were found in the sandstone, siltstone and mudstone. The braided fluvial deposits are present mainly in the middle member of the Xiahedong Formation and middle member of the Haoling Formation (Fig. 2).

\section{TRACE FOSSIL DESCRIPTIONS}

Trace fossils are abundant in the sandstone, siltstone and mudstone beds of the Xiahedong, Haoling and Shangdonggou Formations. Common ichnotaxa include Psilonichnus ichnosp., Arenicolites ichnosp., Palaeophycus tubularis, Scoyenia ichnosp., Planolites montanus, Planolites ichnosp., Skolithos ichnosp., and other burrows and rhizoliths.

\subsection{Palaeophycus tubularis (de Saporta, 1872)}

This ichnospecies is a simple, unbranched or sparsely branched, straight to curved burrow with a distinct lining, having identical infill to the host rock. These burrows are parallel or inclined to the bedding plane (Figs 5a-5d). Overcrossing of different specimens is common. The burrow diameter is 5 to $30 \mathrm{~mm}$, visible length is 8 to 15 $\mathrm{cm}$. Preserved on the bedding plane and bottom of finegrained sandstone or in muddy siltstone. Generally, this kind of burrow is thought to represent dwelling traces of suspension feeders or predators (Pemberton \& Frey, 1982). The trace fossils occur mostly in the Cretaceous sandstones of the Ruyang Basin and are interpreted as having formed in a channel fill sedimentary environment.

\subsection{Psilonichnus ichnosp.}

The ichnofossils are "Y" or "J"-shaped burrows (Figs 6a$6 \mathrm{~b})$, which are vertical or steeply inclined to the bedding 

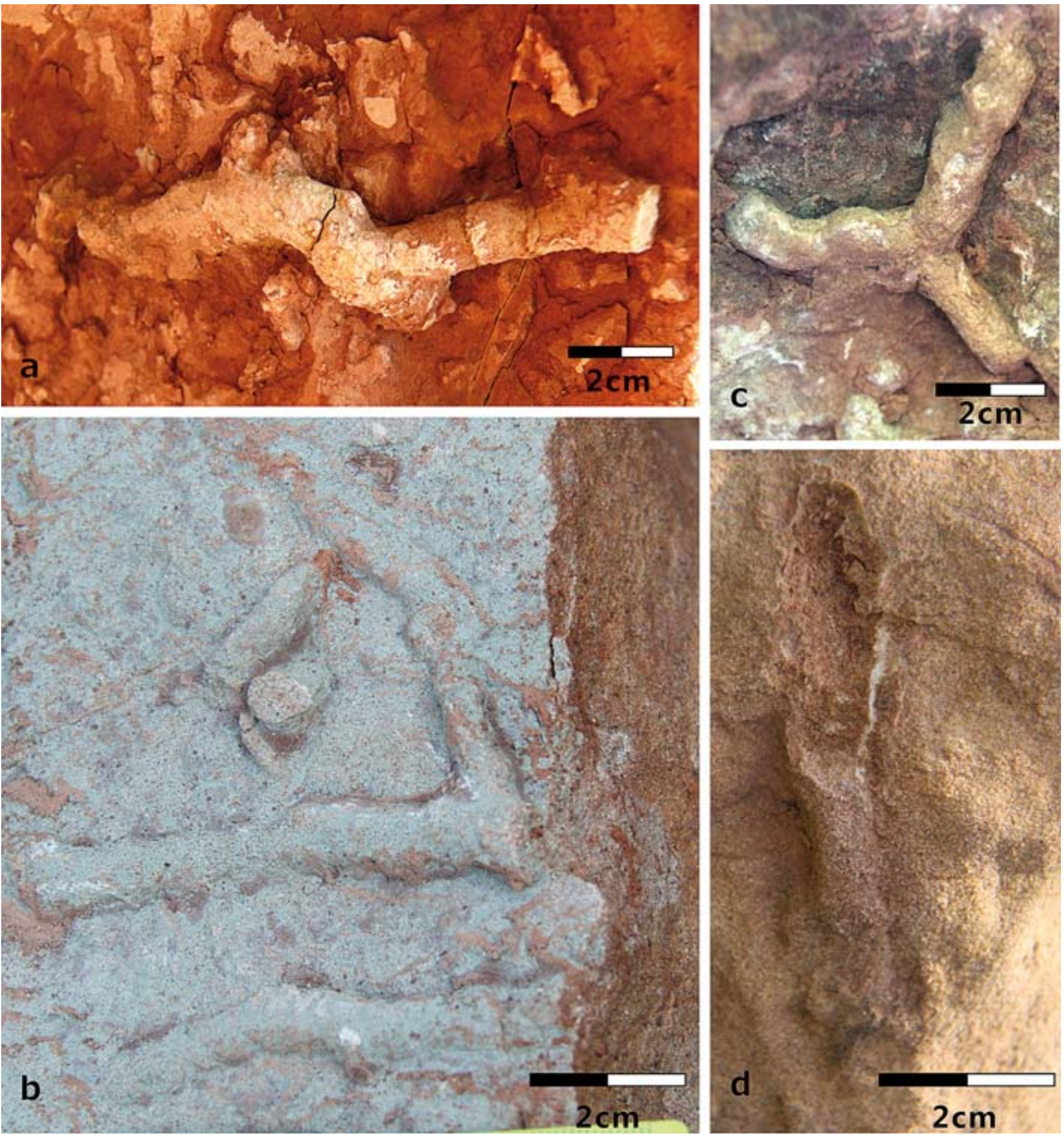

Figure 5. Palaeophycus tubularis in the Cretaceous of the Ruyang Basin. a-b) From the middle part of the Xiahedong Formation. c-d) From the middle part of the Haoling Formation.

plane. The diameter of burrows is 6 to $46 \mathrm{~mm}$, and the length is 15 to $60 \mathrm{~mm}$. Burrow fill is identical to the overlying sediments. These burrows occur with dinosaur fossils in fine-grained sandstone in the middle part of the Lower Cretaceous Haoling Formation.

In the geologic record, Psilonichnus has been found mostly in backshore environments along marine coastlines
(Nesbitt \& Campbell, 2002, 2006). However, it also has been found in some terrestrial environments (Frey \& Pemberton, 1987). The trace makers are mainly suspension feeders or mud eaters, such as decapod crustaceans (e.g., crabs, shrimps and crayfish). These trace fossils have been reported in several different types of continental environments (Fürsich, 1981; Frey et al., 1984; Hasiotis 
\& Mitchell, 1993; Bedatou et al., 2008). Sedimentary characteristics suggest that these burrows were produced in a setting of moderate water energy in a seasonally or climatically controlled intra-fan pond in a foodplain.

\subsection{Arenicolites ichnosp.}

The ichnofossils are "U" or "W"-shaped burrows (Fig. 6a), which are vertical or steeply inclined to the bedding plane. A spreite is not observed. The single pipe diameter of burrows is 10 to $32 \mathrm{~mm}$, width between two pipes is 18 to $25 \mathrm{~mm}$, and the length (or vertical depth) is 26 to $35 \mathrm{~mm}$. Burrow fill is identical to the overlying sediments. These burrows occur with dinosaur fossils and Psilonichnus in fine-grained sandstone in the middle part of the Lower Cretaceous Haoling Formation.

\subsection{Skolithos ichnosp.}

This ichnospecies is based on several specimens in field occurrences (Figs 7a-7c). It is an unwalled vertical burrow that is oriented nearly perpendicular to bedding and showing a circular cross-section with a diameter of 5 to $10 \mathrm{~mm}$ and a length of 3 to $13.5 \mathrm{~cm}$. Burrow fill is similar to the overlying red silty mudstone. These burrows were observed mostly in fine-grained sandstone of channel fill deposits in the Lower Cretaceous Xiahedong and Haoling Formations.

\subsection{Scoyenia ichnosp.}

Scoyenia is very common in the Lower Cretaceous alluvial and lacustrine deposits of western Henan Province, but the burrow is not well preserved in the Xiahedong and Haoling Formation. It a slightly curved tubular burrow with a crescent backfill structure, up to $9 \mathrm{~cm}$ in length and $9 \mathrm{~mm}$ in width, and wall scratchings can be observed (Fig. 8). The burrows occur in red muddy siltstone with horizontal laminae, and they are oriented parallel to the bedding plane. Based on sedimentary characteristics of the host rock, these burrows probably were formed in an overbank or floodplain environment.

\subsection{Planolites montanus (Richter, 1937)}

The specimen is a simple, unbranched, straight to slightly curved, cylindrical to subcylindrical burrow, having infill same as that of the host rock (Fig. 9a). Diameter is 1 to $2 \mathrm{~mm}$ and observed length is $8.5 \mathrm{~cm}$. It was preserved in semirelief in silty sandstone with horizontal laminae, and it was oriented more or less horizontal or oblique to the bedding plane. This trace fossil was produced in floodplain deposits in the Lower Cretaceous Xiahedong Formation.

\subsection{Planolites ichnosp.}

This specimen was found in the middle member of the Lower Cretaceous Xiahedong Formation. It is a smooth,
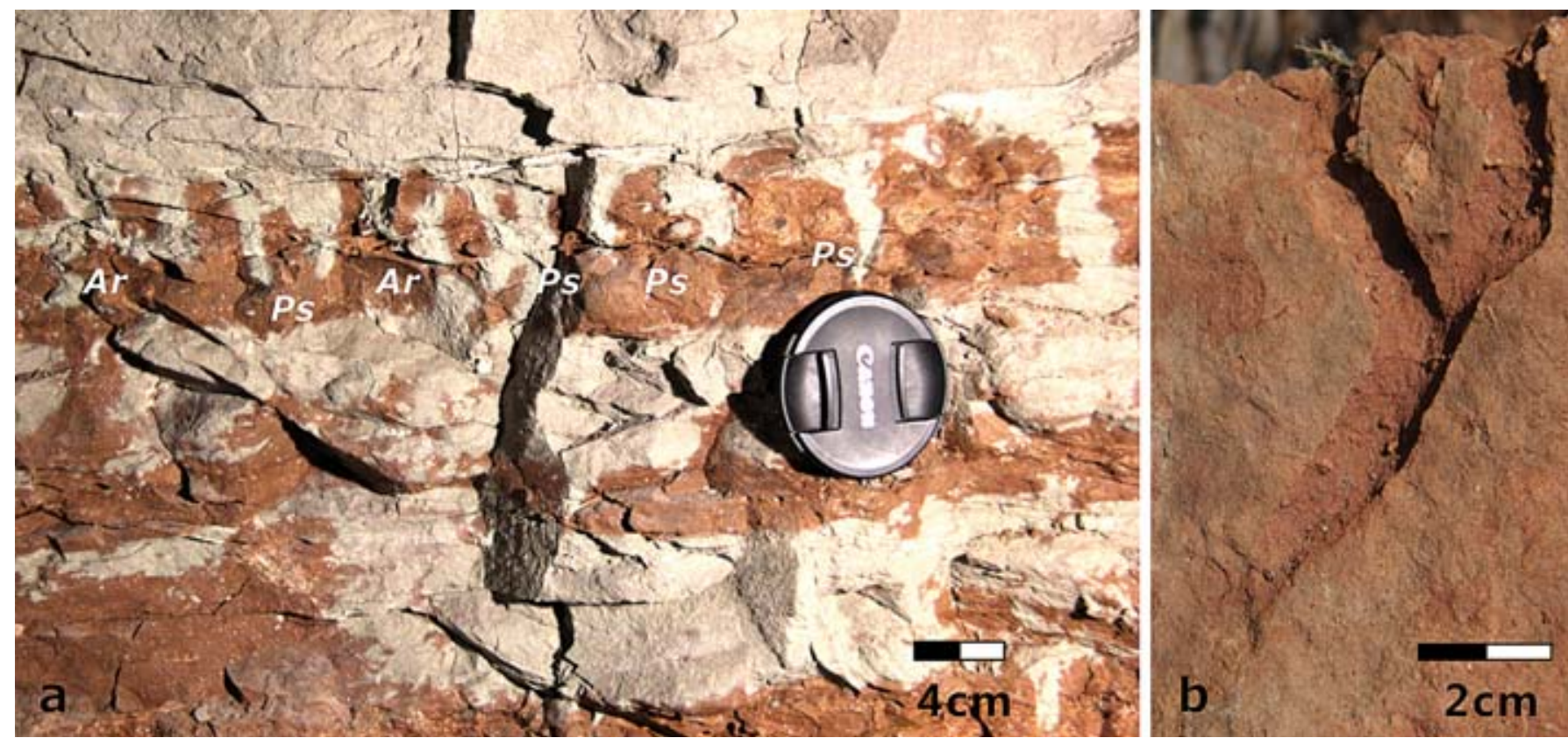

Figure 6. Psilonichnus $(P S)$ and Arenicolites (Ar) in the Cretaceous of Ruyang Basin. a) Psilonichnus ichnosp. and Arenicolites ichnosp. from the lower part of the Haoling Formation. b) Psilonichnus ichnosp. from the middle part of the Xiahedong Formation. 

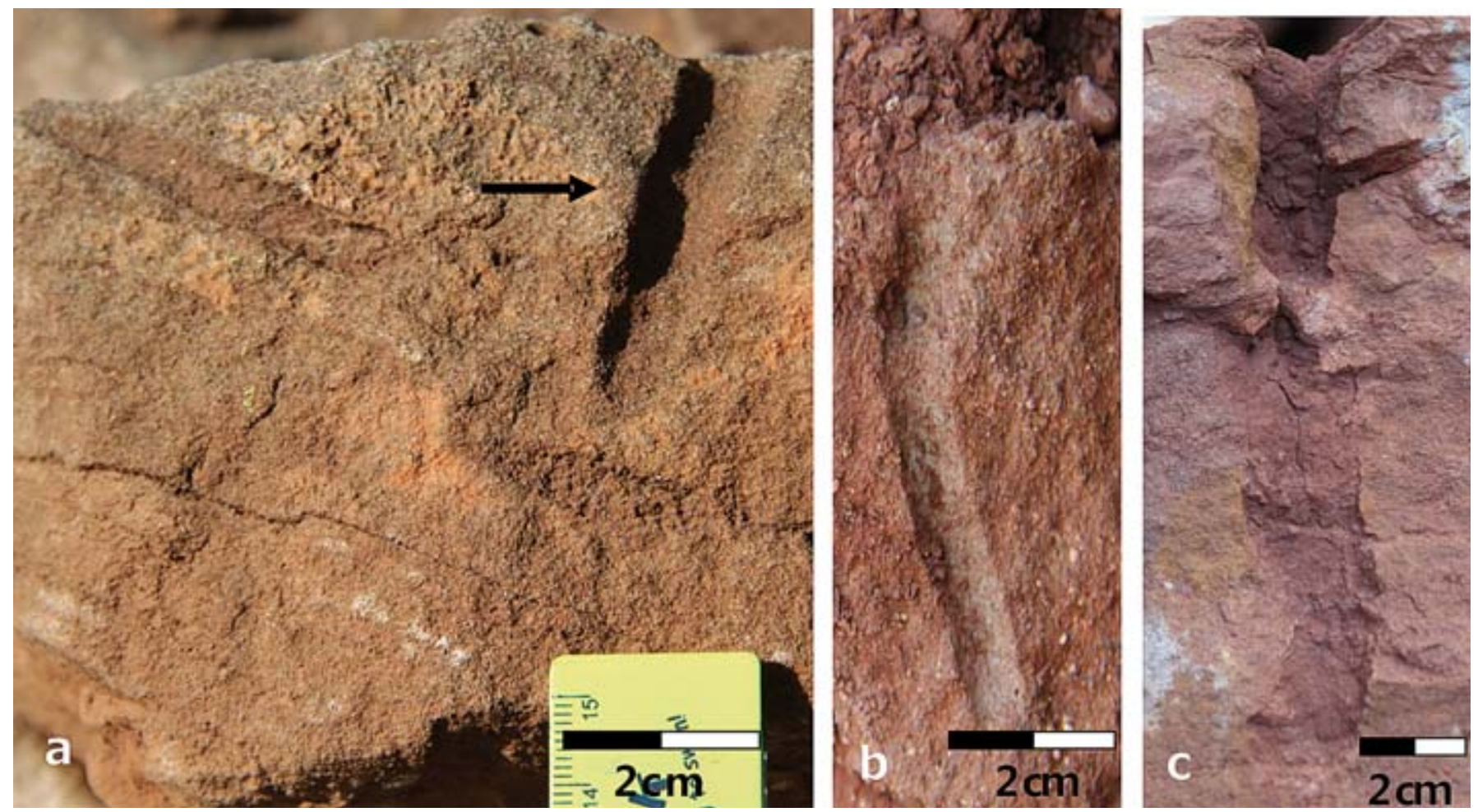

Figure 7. Skolithos in the Lower Cretaceous of the Ruyang Basin. a-c) Skolithos ichnosp. from the middle part of the Xiahedong Formation.

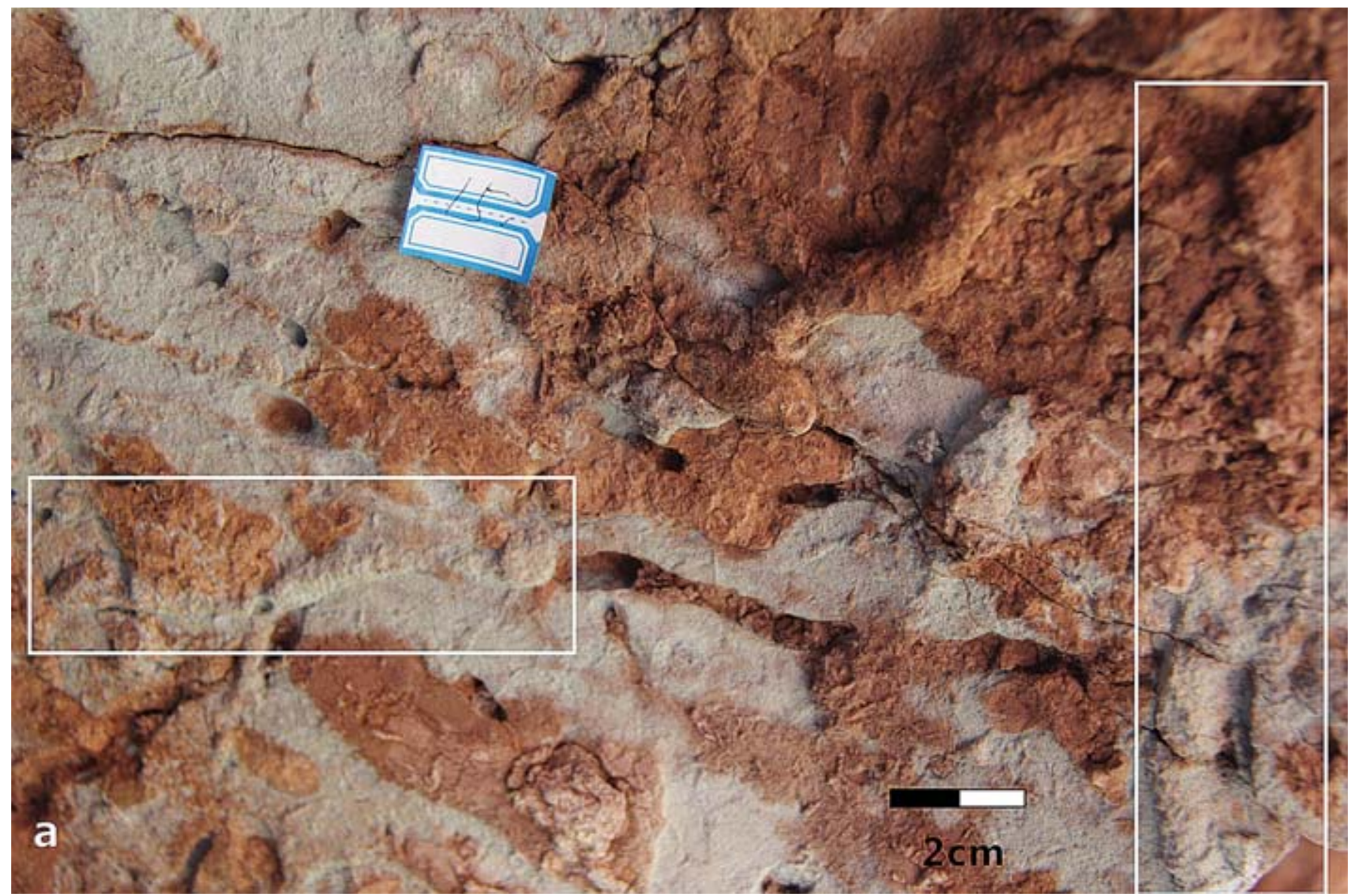

Figure 8. Scoyenia from the middle part of the Xiahedong Formation in the Ruyang Basin. 
straight to gently curved, unbranched burrow that is parallel to bedding. The burrow is 5 to $11 \mathrm{~mm}$ in diameter and up to $16 \mathrm{~cm}$ in visible length. The burrow appears to become wider toward both ends, where it is about twice as wide as in the narrow middle part. Burrow fill is preserved in hyporelief in fine-grained sandstone (Fig. 9b).

\subsection{Other bioturbation structures}

Other bioturbation structures refer to unidentified vertical or inclined burrows in the muddy siltstones (Figs 10a-10b). Commonly, they appear singly or in groups, but it is difficult to identify their ichnogenus or ichnospecies. These burrows are mostly 2 to $20 \mathrm{~cm}$ long and 1.5 to $2 \mathrm{~cm}$ wide, and they are passively filled. Depositional characteristics show that they are mainly present in a floodplain environment.

\subsection{Rhizoliths}

Root traces are preserved at the contact between the red interbedded fine-grained siltstone and mudstone (Figs 10c-10d). They are oriented vertically or slightly inclined to bedding. The root traces are 2 to $15.8 \mathrm{~cm}$ long and 2 to $19 \mathrm{~mm}$ wide. They are filled with fine-grained oxidized sediments, and they were produced in floodplain environments.

\section{ICHNOFOSSIL ASSEMBLAGES AND THEIR SEDIMENTARY ENVIRONMENTS}

Ichnofossils in the Cretaceous terrestrial deposits of the Ruyang Basin include six ichnospecies, together with unidentified burrows and root traces. Based on their composition, distribution, occurrence and sedimentary environments, two ichnoassemblages are recognized (Fig. 11).

\subsection{Scoyenia-Skolithos ichnoassemblage}

This assemblage mainly consists of Scoyenia, Skolithos, Planolites, Palaeophycus and rhizoliths. Palaeophycus and Skolithos are preserved in medium to fine-grained lithic sandstone intercalated with red silty mudstone. Planolites, Scoyenia and rhizoliths occur in alternating layers of siltstone and brownish red silty mudstone. Dinosaur skeletal elements belonging to several different taxa (Xu et al., 2010) were found in the silty mudstone and siltstone containing the ichnofossils. The ichnoassemblage was produced in the lithofacies Fsm and St, so it is interpreted as having formed in a braided fluvial environment of an alluvial fan system (Fig. 11a).
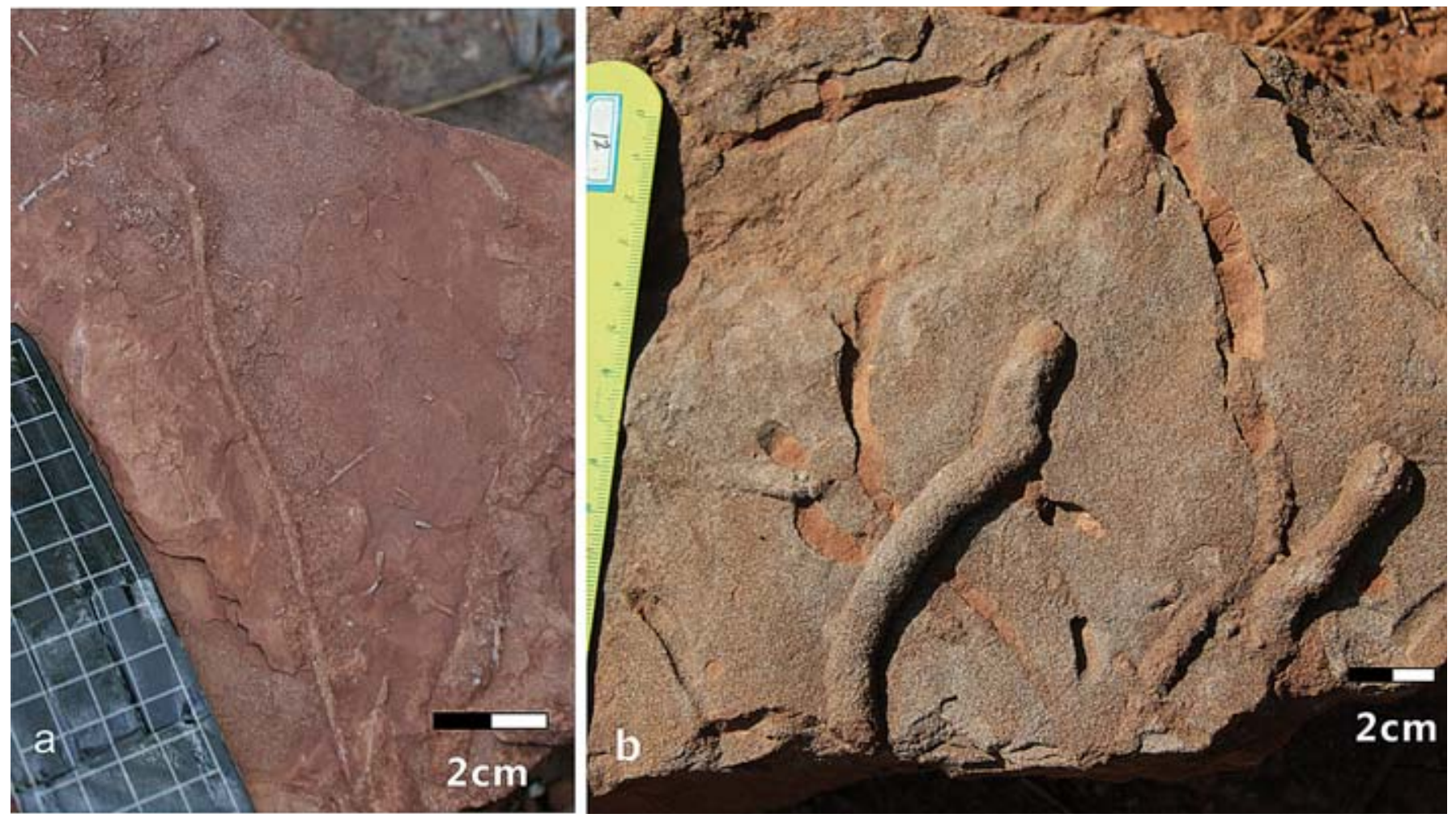

Figure 9. Planolites from the middle part of the Xiahedong Formation in the Ruyang Basin. a) Planolites montanus. b) Planolites ichnosp. 

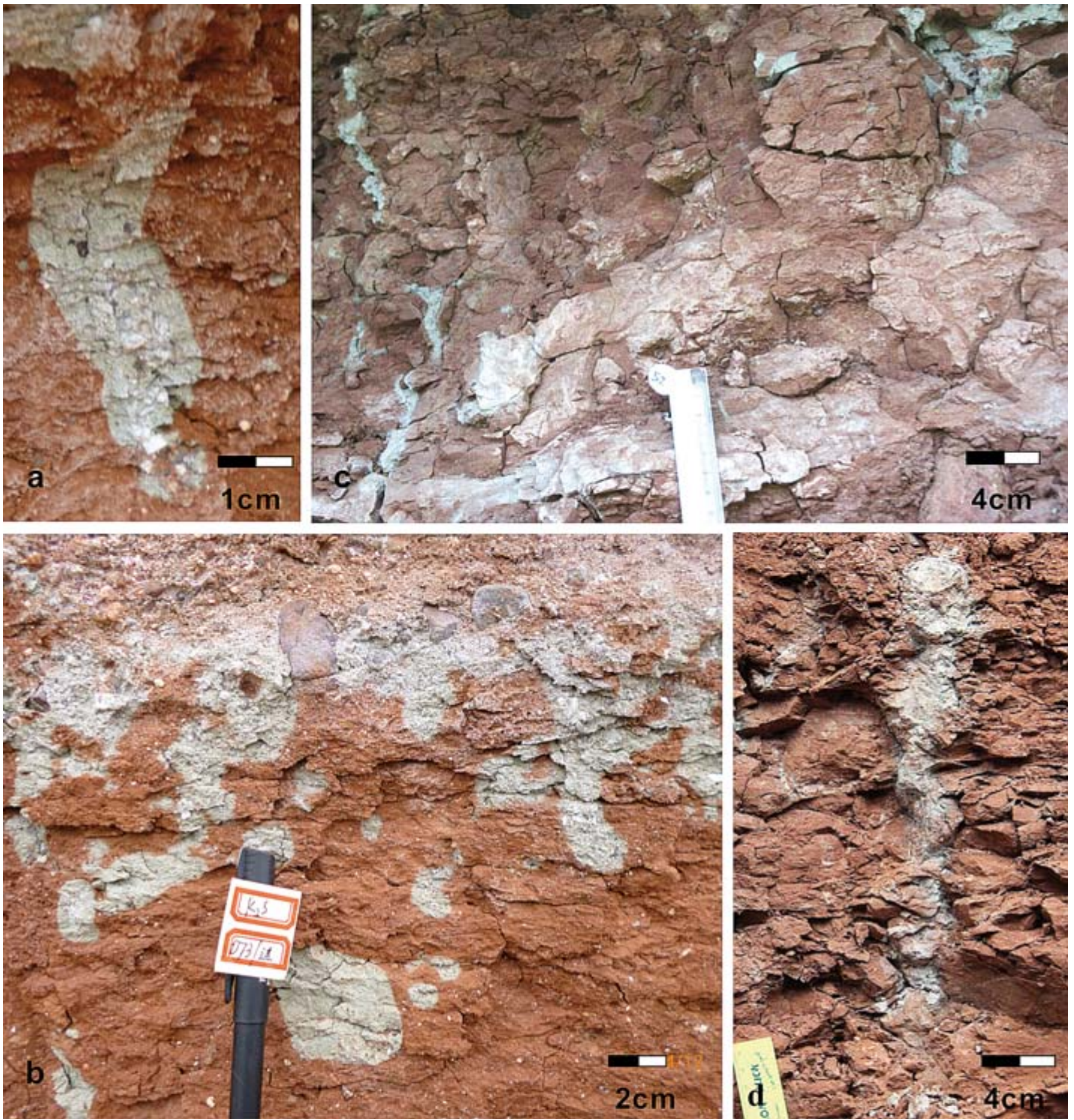

Figure 10. Cretaceous ichnofossils in the Ruyang Basin. a-b) Bioturbation from the lower part of the Shangdonggou Formation. c-d) Rhizoliths from the middle part of the Haoling Formation.

\subsection{Psilonichnus-Palaeophycus ichnoassemblage}

This ichnoassemblage is characterized by abundant Psilonichnus, Palaeophycus and Arenicolites, plus lesser numbers of Skolithos. Palaeophycus occurs in alternating layers of sandy conglomerate and brownish red muddy siltstone or sandy mudstone in the Haoling Formation, and it was formed in a middle fan to fan edge sedimentary environment (Fig. 11b).

Psilonichnus and Arenicolites are present in lithofacies Fm. It is interpreted as having formed in a shallow pond or lake within the fan edge subfacies. It is noteworthy that the associated dinosaur fossils, such as Zhongyuansaurus 
luoyangensis, were discovered in the same layer along with Psilonichnus, Arenicolites and Skolithos. Because this was an extremely shallow pond or lake environment at the edge of an alluvial fan, the preservation of dinosaur fossils in this setting suggests that it may be a flood event deposit.

As mentioned above, the lithofacies and ichnoassemblages indicate that the Cretaceous Xiahedong, Haoling and Shangdonggou Formations in Ruyang basin of western Henan were generated in a depositional environment of alluvial fans in association with braided rivers (Fig. 11).

\section{CONCLUSIONS}

Based on the study of lithology, sediment texture, primary sedimentary structures and trace fossils, eight lithofacies (Gmm, Gcm, Gm, Gt, St, Sm, Fm and Fsm) are distinguished

\section{ACKNOWLEDGMENTS}

This research was supported by the National Science Foundation of China (Grant No. 41272117), the Specialized Research Fund for the Doctoral Program of Higher Education of China (Grant No. 20094116110002), and the Developing Projects of Science and Technology of Henan Province (Grant No. 124300510039, 092300410167). Special thanks to A.A. Ekdale for suggestions to modify the paper.

\section{REFERENCES}

Bedatou, E., Melchor, R.N., Bellosi, E. \& Genise, J.F. 2008. Crayfish burrows from Late Jurassic-Late Cretaceous continental deposits of Patagonia, Argentina: their

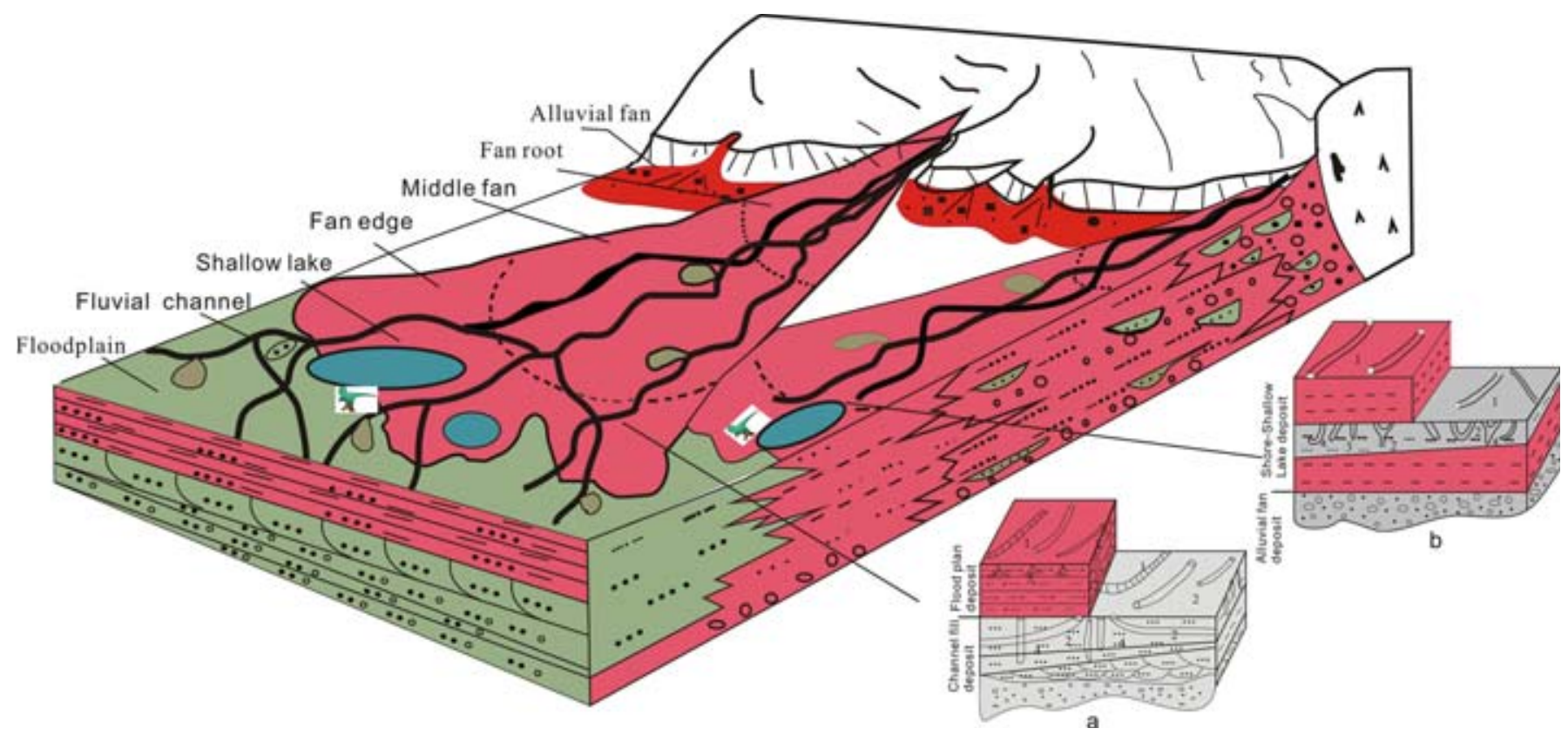

Figure 11. Model of the Cretaceous sedimentary setting and associated ichnofossils in the Ruyang Basin. a) Scoyenia-Skolithos assemblage: 1-Scoyenia, 2-Palaeophycus, 3-Planolites, 4-Skolithos, 5-rhizoliths. b) Psilonichnus-Palaeophycus assemblage: 1-Palaeophycus, 2-Areniocolites, 3-Skolithos, 4-Psilonichnus.

in the Cretaceous Xiahedong, Haoling and Shangdonggou Formations in the Ruyang Basin of western Henan Province. Two distinct ichnoassemblages are recognized in these sequences (Scoyenia-Skolithos ichnoassemblage and Psilonichnus-Palaeophycus ichnoassemblage). They were produced in a braided fluvial environment of an alluvial fan system and in a shallow pond or lake at the edge of the alluvial fan system, respectively. palaeoecological, palaeoclimatic and palaeobiogeographical significance. Palaeogeography, Palaeoclimatology, Palaeoecology, 257, 169-184.

Frey, R.W., Curran, H.A. \& Pemberton, S.G. 1984. Tracemaking activities of crabs and their environmental significance: the ichnogenus Psilonichnus. Journal of Paleontology, 58, 333-350.

Frey, R.W. \& Pemberton, S.G. 1987. The Psilonichnus ichnocoenose and its relationship to adjacent marine 
and nonmarine ichnocoenoces along the Georgia coast. Bulletin of Canadian Petroleum. Geology, 35, 333-357.

Fürsich, F.T. 1981. Invertebrate trace fossils from the Upper Jurassic of Portugal. Comunicações dos Serviços Geológicos de Portugal, 67, 153-168.

Hasiotis, S.T. \& Mitchell, C.E. 1993. A comparison of crayfish burrow morphologies: Triassic and Holocene fossil, paleoand neo-ichnological evidence, and the identification of their burrowing signatures. Ichnos, 2, 291-314.

Huang, Z., Gao, C. \& Ji, R. 2005. The Meso-cenozoic basin evolution in the south of north China. Oil \& Gas Geology, 26, 252-256.

Lv, J., Huang, Z. \& Zhai, C. 2005. Basin forming analysis of Meso-cenozoic basin in the south of north China. Petroleum Geology \& Experiment, 27, 118-123.

Nemec, W., Porbski, S.J. \& Steel, R.J. 1980. Texture and structure of resedimented conglomerates: examples from Ksiaz Formation (Famennian-Tournaisian), southwestern Poland. Sedimentology, 27, 519-538.
Nesbitt, E.A. \& Campbell, K.A. 2002. A new Psilonichnus ichnospecies attributed to mud shrimp Upogebia in estuarine settings. Journal of Paleontology, 76, 892-901.

Nesbitt, E.A. \& Campbell, K.A. 2006. The paleoenvironmental significance of Psilonichnus. Palaios, 21, 187-196.

Pemberton, S.J. \& Frey, R.W. 1982. Trace fossil nomenclature and the Planolites-Palaeophycus dilemma. Journal of Paleontology, 56, 843-881.

Xu, L., Zhang, X. \& Lv, J. 2010. The discussion of Henan RuYang giant sauropod dinosaur fauna and fossiliferous strata era. Geological Review, 56, 761-768.

Yu, H., Han, S. \& Xie, J. 2006. Prototype sedimentary basin type and tectonic evolution in southeast of north China plate. Oil \& Gas Geology, 27, 244-252.

Zhang, X., Zhou, D. \& Zhao, W. 2007. Tectonic styles and oil and gas exploration in west Henan Province of China. Journal of Northwest University (natural science edition), 4, 647-652. 